\title{
Drivers of Residential Energy Saving
}

\author{
Orose Leelakulthanit ${ }^{1}$ \\ ${ }^{1}$ NIDA Business School, National Institute of Development Administration, Bangkapi, Bangkok, Thailand \\ Correspondence: Orose Leelakulthanit. Tel: 66-2-727-3966. Fax: 66-2-374-3282. E-mail: orose@nida.ac.th
}

Received: September 28, 2017

doi:10.5539/ass.v13n12p125

\author{
Accepted: October 29, 2017 \\ Online Published: November 28, 2017 \\ URL: https://doi.org/10.5539/ass.v13n12p125
}

\begin{abstract}
One of the main strategies in dealing with the problem of global warming in today's world is saving energy or employing an efficient use of energy. It is the intention of this study to investigate the determinants of residential energy saving. Seven motives for residential energy saving have been identified: the benefits of saving money, and solving the global warming problem, as well as accepting responsibility for energy, knowing how to save energy, committing to the saving of energy saving through pledges, having a role model for energy saving, and comparing the current energy bill with the previous months' bills. A total of 350 responses were collected from self-identified adult energy saving shoppers in Bangkok. The results of the multiple regression analysis indicated that the positive factors affecting residential energy saving were commitment to energy saving through making pledges, saving money, accepting saving energy as the person's responsibility, knowing how to save energy, and comparing one's current energy bill with that of the previous months. The analysis of the effective strategies for residential energy saving will be discussed.
\end{abstract}

Keywords: driver, determinant, motivation, energy saving, energy efficiency, residential

\section{Introduction}

Improvements in energy efficiency are a good idea, both in terms of business investment and as something that is vital for the global community. As with investment in renewable energy sources, for example wind and solar energy, investment in efficient energy presents great opportunities, particularly regarding the reduction of the use of fossil fuels such as gas, oil and coal. As a result, this will assist with the reduction of greenhouse gas emissions and hence the threat of change in the climate. According to the Asian Development Bank (ADB, 2015), Thailand and other Greater Mekong Subregion (GMS) countries-Cambodia, the Lao People's Democratic Republic (Lao PDR), Myanmar, and Vietnam-anticipate that the energy demand will triple over the next 15 to 20 years. In order to meet this increased demand, it is necessary to do more than simply add to the current domestic and imported energy supplies; that is, greatly-improved energy efficiency must also be included as an important part of the response to the current energy situation. The GMS countries need to make their supply- and demand-side energy efficiency measures part of the mainstream and in all sectors of their economies. Supply-side energy savings, for example, come mainly from measures implemented by public utilities and private sector investors in order to increase the efficiency of energy generation and to reduce the loss of the transmission and distribution of energy. On the other hand, most demand-side energy savings stems from the investment of industry and commercial users in terms of better production and transportation methods and from the more efficient use of more lighting, heating, and cooling, in addition to other appliances and transport vehicles used by households. The GMS countries foresee substantial energy savings over the next 15 to 20 years, and it has been asserted that Thailand will exhibit in its industry and transport sectors the highest energy savings score-from $20 \%$ to $40 \%$ (ADB, 2015). In Cambodia, the Lao PDR, and Myanmar the major sources of savings are seen to come from the residential and commercial sectors, and regarding Vietnam, the energy savings are expected to be the greatest in the industrial sector. It is important to remember that Thailand still does not pay much attention to energy savings in its residential sector, and this is significant since this sector uses $14.8 \%$ of the total energy in the country, third ranked after the industrial sector (36.8\%) and the transportation sector (35.8\%). It is the purpose of this study to investigate the factors affecting the energy saving in its residential sector.

\section{Literature Review}

\subsection{Saving Money}

Aravena et al. (2016) investigated the implementation of seven energy-efficient measures in the residential houses in Ireland, and the results indicated that the decision to invest in energy-efficient measures mainly derived from monetary or economic factors, for example, the gain in energy savings and the cost of measures on a private level. Comfort gains, on the other hand, were found to be a secondary factor, of little concern were the environmental benefits of energy-efficient measures, particularly when making investment decisions. Another study conducted by the U.S. Department of Energy (2013) indicated that saving money is the overwhelming motivating factor in people's decision to make improvements in their use of energy: everything else was seen to be secondary. Some of the participants in the focus groups in that study were seen to be concerned about protecting the environment and they indicated that that was what motivates them to take action regarding the use of energy: they want to "be responsible," "feel less guilt," "help 
the government," and "do their part" since it's a "small planet with depleting resources." Others were motivated by necessity; that is, something breaks for example and they want to fix it. Other reasons for making energy improvements included improving the value of the home, reducing maintenance costs, and increasing their comfort and improving their health (e.g., allergies) and safety (carbon monoxide poisoning). "Quietness" or less noise resulting from energy improvement was also perceived as a benefit of energy savings leading to one's comfort; some were even seen to be motivated by the desire to improve the appearance of their home or to be motivated by peer pressure, that is, "keeping up with the Joneses." More specifically, a recent study by Leelakulthanit (2017) has suggested that saving money is the main concern in promoting energy-saving behaviors in the use of air conditioners in Thailand. Therefore, it can be hypothesized that saving money is positively related to the saving of energy.

\subsection{Environmental Benefits}

Clear individual benefits can be connected with sustainable energy behaviors. For example, some people may enjoy walking or riding a bicycle more than driving a car, a person can save money at home by using less energy, and using an electric vehicle can enhance a person's perception of his/her status level. However, energy behaviors that are sustainable often cost a lot and require effort, and they are sometimes considered to be unpleasant. For example, insulating one's home or installing solar panels can be considered troublesome and as costing a good deal of time and effort. Investing in energy-efficient technology can also be costly, and switching off appliances can be thought to require more trouble than it's worth, and some people think that using certain appliances only when renewable energy sources are available limits their freedom of choice. Nevertheless, many people do engage in these behaviors despite their perception of these behaviors requiring money and effort. One of the questions to ask in this context is "What motivates people to engage in sustainable energy behavior that leads to higher expenditure of money and effort? People should not only consider the individual consequences of their behavior, but also broader consequences, and they should understand that sustainable energy behavior benefits the environment as it can result in the reduction of $\mathrm{CO} 2$ emissions (Steg et al., 2014). It has been asserted that people are motivated to see themselves as engaging in morally-responsible behavior, such as sustainable energy behaviors, and this makes them feel that they are "doing the right thing" (Bolderdijk et al., 2013). This suggests that sustainable energy behavior is not only a product of individual considerations but is also a product of moral considerations. In fact, several studies have shown that moral considerations have a strong influence on sustainable energy behavior, such as the purchase of energy-saving light bulbs and making changes in the eating of meat products (Harland et al., 2007), Also cited in this connected is electricity saving at work (Zhang et al., 2013), energy-saving behaviors at home (Van der Werff \& Steg, 2015), and the acceptability of energy policies (Steg et al., 2005; Steg \& De Groot, 2010). It has also been suggested that becoming involved in sustainable energy behavior can make people feel good about themselves because they derive pleasure and satisfaction, as stated above, from doing the right thing (Bolderdijk et al., 2013; Venhoeven et al., 2013; Taufik et al., 2014). Thus, it can be hypothesized that seeing the benefit of helping to solve the global warming problem is positively related to energy saving.

\subsection{Responsibility}

When we talk about perceived responsibility it means taking responsibility for energy conservation oneself (for example via self-blame, liability and personal obligation) rather than attributing that responsibility to someone else such as the government, environmental groups, industry or other external parties (Van Raaij \& Verhallen, 1983). It has been often argued that feeling personally responsible for environmental problems, that is, blaming oneself for damage to the ecology and for protecting the environment, for example feeling the necessity to fight climate change oneself by driving a more efficient car can be associated with pro-environmental behavior in a positive way. In fact a number of researchers have suggested that when people feel personally responsible for environmental problems they tend to feel a stronger obligation to help reduce those problems and consider this to be a moral responsibility. It has also been suggested that when people feel this personal responsibility it increases their desire to act in a pro-environment way (see for example Abrahamse \& Steg, 2011, 2009). On the other hand, if one denies his or her responsibility, that responsibility may be assigned to an external entity, thus implying that there is no need to change one's behavior (Van Raaij \& Verhallen, 1983). Hummel et al. (1978) (cited in Van Raaij \& Verhallen, 1983) found in their empirical study that perceived self-blame on the part of energy consumers was related to a greater desire to save energy; on the other hand, blaming an external entity for the energy problems was seen to be related to a diminished desire to conserve energy. In research following the above-cited study, Hines et al.(1987) suggested that personal responsibility can be expressed in many ways. For example it can be expressed in terms of the entire environment in terms of protecting it and in terms of being socially responsible to the community in which one lives. It can also be expressed in terms of only one aspect of the environment. These authors, using a meta-analysis, concluded that people that feel responsible for the environment are more likely to perform responsible environmental behavior than those that do not feel this responsibility. Thus, it can be hypothesized that realizing that saving energy is one's responsibility can be seen to be positively related to energy saving.

\subsection{Knowledge}

People often do not understand the extent to which their behavior adds to climate change. For example, few people probably know that heating and cooling one's home contribute to global warming (Bord et al., 2000). People have different perceptions of how what they do contributes to global warming, and typically people think that the causes of 
global warming are activities outside their personal realm, for example industry, rather than their own behavior (Whitmarsh et al., 2011). Further, people's perceptions of their energy are not always accurate and this suggests that they may not be able to accurately judge the behavior that will effectively reduce energy consumption and CO2 emissions - in fact, people tend to rely on a simple method when judging their household energy use- the size of appliances. The larger that the appliance is, the greater is the energy used according to this line of thought (Baird \& Brier, 1981; Schuitema \& Steg, 2005). This of courses is not always true and can lead to the underestimation of the use of energy of certain small appliances, such as phone chargers, and the overestimation of the energy use of large appliances, like fans. In addition, people tend to underestimate the energy needed to heat water. This implies that people are not aware that they can save energy by taking fewer showers for example (Schuitema \& Steg, 2005). Additionally, people think that they can save more energy by using appliances less, for example by turning lights off, rather than through improvements in efficiency, for example by installing higher-efficient light bulbs (Attari, 2010). In fact, the opposite is true according to experts.

Unfortunately knowledge is not always strongly related to environmental behavior, and this includes behavior regarding the use of energy. While some studies have demonstrated that greater environmental knowledge increases the likelihood of behavior that sustains energy (Hines et al., 1986/1987; Frick et al., 2004), other studies have shown that increased knowledge does not promote such behavior (Schahn \& Holzer, 1990; Kollmuss \& Agyeman, 2002; Meinhold \& Malkus, 2005; Vicente-Molina et al., 2013). Not only that, but research has pointed out that different types of knowledge can predict environmental behavior in different ways, and that only knowledge related to action (for example understanding what you can do about environmental problems) and effectiveness (i.e., knowing the benefits or effectiveness of actions that support the environment) is able to predict environmental behavior (Steg et al., 2015). In this study, knowledge refers to knowing how to save energy at home, and therefore it can be hypothesized that knowledge of how to save energy is positively related to energy saving.

\subsection{Pledging}

Commitment making is commonly regarded as an effective way to promote the behaviors that support the care for the environment; and the general idea is that when people engage in certain types of behavior, they adhere to this engagement, resulting in behavior change over time. Werner et al.'s (1995) study revealed that obtaining a signed commitment increased recycling in Salt Lake City, Utah, more than when the participant receive a flyer or a telephone call. A variety of studies in fact have highlighted when commitments are likely to be most adhered to. Written commitments appear to be more effective than verbal commitments (Pardini \& Ketzev, 1983-84). In a study that investigated the impact of verbal as opposed to written commitments, households were assigned to one of three groups. In the first group, homes simply received a pamphlet underlining the importance of recycling newspapers, while in the second group, households made a verbal pledge to recycle newsprint. In the third group, a person in the household signed a statement whereby he/she committed him/herself to recycling newspapers. In the beginning, the households that made a verbal commitment recycled more newsprint than the households that received only a pamphlet; however, in the end only the individuals that committed themselves to recycling by signing a statement were still found to be recycling when a follow-up took place. Public commitment has perhaps a more striking impact, which was illustrated in a study in which either private commitment to conserving electricity and natural gas was obtained, or public commitment was obtained. In the latter case the names would be published in the local newspaper. It was found that those that agreed to the commitment publically saved much more energy than did the individuals that made a private commitment. In the latter case, even after the researchers indicated that their names would not be published, they continued to save energy. It can be seen then that even though their names were not publicized, merely asking for this permission created about a $15 \%$ reduction in natural gas use and a $20 \%$ reduction in electricity. It is also significant that these reductions could still be seen 12 months later (Pallak et al., 1980). This public commitment was perhaps so effective because of people's desire to be consistent. In can be tentatively concluded then that the more public a commitment is, the more likely it is that people will honor that commitment. In a study conducted by Lokhorst et al. (2013), the authors investigated why commitment is effective, and in order to find the answer, the authors first presented a meta-analysis of environmental studies that contained a commitment manipulation. Then, they investigated the psychological constructs that were possibly responsible for the commitment. They concluded that making a commitment leads to behavior change in the short and long term, especially when compared with controlled conditions. Thus, it can be hypothesized that commitment to saving energy through pledging is positively related to energy saving.

\subsection{Role Model}

People can be highly influenced by their social surroundings, and this includes relatives, friends, colleagues, and others (Han et al., 2010). Grob (1995) also has stated that the differences that have appeared in environmental attitudes and behaviors may have been a result of social group memberships. Bush, Martin \& Clark (2001) discussed the consumer socialization process through the use of social learning theory, and demonstrated that direct role models such as fathers, mothers, and others had the greatest impact on consumers' knowledge of the market and on their purchase decisions, especially with reference to the attitudes of young adults (Bush et al., 2001). Consumer socialization can be characterized as follows: a process according to which consumers increase their knowledge and skills, and form attitudes towards their purchases (Bush et al., 2001). It can also be seen that celebrity role models also create this kind 
of social pressure, but this most often takes place with reference to the purchase of high-status and expensive products. Entertainers and athletes are also a good source of product information (Bush et al., 2001). Therefore, it can be hypothesized that having a role model for energy saving is positively related to energy saving.

\subsection{Temporal Comparison}

The temporal comparison theory defines temporal comparison in terms of when a person compares him/herself at two different points in time (Albert, 1977). Previous research on self-comparison feedback has revealed that the comparison of person's achievements in the past with those in the present can be effective in terms of motivating a person to act, particularly when it is assumed that the previous consumption was less than in the present (Becker, 1978). This type of information can demonstrate the more obvious trends in behavior (e.g., energy consumption or frequency of physical activities) over wide-ranging periods of time. The users reflect on the reasons for their particular behavior and on its context. With reference to energy conservation, Fitzpatrick \& Smith (2009) stated that such a comparison is often made along with exploration of the energy consumption data and increased awareness of normal everyday usage patterns. Moreover, a focus group study in the UK revealed that there was an "overwhelming preference for simple comparison of historical data" (Roberts et al., 2004). It follows that knowing what the current energy bill is compared with that of previous months can be positively correlated with energy saving.

\section{Methodology}

\subsection{Sampling}

The questionnaire used in this study was first tested with 7 MBA students in order to obtain a preliminary understanding of the content. This was followed by a pretest, where 7 eligible adult respondents at least 18 years of age were interviewed and were individuals that identified themselves as persons that saved energy at home. The questionnaire was revised based on the feedback from the interviewees in terms of its suitability and clarity, and then the main study was conducted interviewing 350 eligible shoppers at 14 shopping centers in Bangkok. The rate of energy savers was $76 \%$ and the response rate was $83 \%$.

\section{Data analysis}

The benefits of saving money and helping to solve the global warming problem, as well as assuming energy saving as the person's responsibility, knowing how to save energy, making a commitment to energy saving through pledging, having a role model for energy saving, and comparing the current energy bill with that of the previous month(s) were assumed to be positively related to residential energy saving. In order to investigate whether this hypothesis held true or not, a regression analysis was conducted. Specifically, the earlier-mentioned independent variables as well as the demographic characteristics, including gender, age, marital status, education, and household income, which were also used as the independent variables because they were used as the controllable variables, were regressed on energy saving, which was used as the dependent variable. It should be noted that education was divided into low education, consisting of people with lower than a bachelor's degree, and high education, consisting of those with at least a bachelor's degree. Household income was also divided into two groups: the low household income group was comprised of persons that earned less than 60,000 baht/month (1 US $\$=33$ baht at time of writing), whereas the high household income group was comprised of those that earned at least $60,000 \mathrm{baht} / \mathrm{month}$.

\section{Results and Discussion}

The results of the multiple regression analysis are shown in Table 1.

Table 1. Results of Multiple Regression of Energy Saving on Its Determinants

\begin{tabular}{|c|c|c|c|c|c|c|c|}
\hline \multirow{2}{*}{ Model } & \multicolumn{2}{|c|}{ Unstandardized Coefficients } & \multirow{2}{*}{$\begin{array}{c}\text { Standardized Coefficients } \\
\text { Beta }\end{array}$} & \multirow{2}{*}{$\mathrm{t}$} & \multirow{2}{*}{ Sig. } & \multicolumn{2}{|c|}{ Collinearity Statistics } \\
\hline & $\mathrm{B}$ & Std. Error & & & & Tolerance & VIF \\
\hline (Constant) & 1.567 & .489 & & 3.203 & .001 & & \\
\hline Save money & .230 & .049 & .240 & 4.735 & $.000^{*}$ & .723 & 1.382 \\
\hline Global warming & -.063 & .043 & -.073 & -1.449 & .148 & .724 & 1.381 \\
\hline Responsibility & .108 & .046 & .129 & 2.356 & $.019^{*}$ & .621 & 1.611 \\
\hline How to save energy & .094 & .048 & .094 & 1.945 & $.053^{*}$ & .794 & 1.259 \\
\hline Pledging & .236 & .037 & .358 & 6.451 & $.000^{*}$ & .604 & 1.657 \\
\hline Role model & .006 & .024 & .011 & .236 & .814 & .870 & 1.150 \\
\hline Temporal comparison & .062 & .033 & .093 & 1.861 & $.064^{*}$ & .737 & 1.357 \\
\hline Gender & -.033 & .092 & -.016 & -.353 & .724 & .947 & 1.056 \\
\hline Age & .002 & .004 & .028 & .496 & .620 & .600 & 1.666 \\
\hline Marrygroup & -.065 & .115 & -.031 & -.563 & .574 & .624 & 1.603 \\
\hline Educgroup & .137 & .100 & .065 & 1.371 & .171 & .818 & 1.222 \\
\hline Incgroup & -.102 & .100 & -.049 & -1.015 & .311 & .797 & 1.254 \\
\hline
\end{tabular}

It suggested that taken together, the 12 independent variables accounted for $42 \%$ of the variance in energy saving $(\mathrm{R}$-square $=.42)$. In addition, saving money, taking energy saving as one's responsibility, knowing how to save energy, 
commitment to energy saving through pledging, and comparing the current energy bill with the previous months had a positive influence on energy saving. According to the standardized beta coefficients, commitment to energy saving through pledging tended to be the most influential on energy saving, followed by saving money, taking energy saving as one's responsibility, knowing how to save energy, and comparing the current energy bill with that of the previous months. It is noteworthy that knowing how to save energy and comparing the current energy bill with the previous months' were more or less equally important in terms of energy saving. It should also be noted that multicollinearity was not a likely problem because the magnitude of the variance inflation factors associated with each independent variable was far less than ten (Wetherill et al., 1986).

Along with the standardized beta coefficient of the significant independent variables in the regression analysis, the mean values for the perceived performance of those independent variables are presented in Table 2 . The mean values were taken from the seven-point anchoring scales, ranging from 1 meaning very little to 7 meaning very much.

Table 2. Importance and performance of drivers of energy saving

\begin{tabular}{ccc}
\hline & Standardized Beta & Mean \\
\hline Pledging & 0.358 & 4.58 \\
Save money & 0.240 & 6.00 \\
Responsibility & 0.129 & 5.65 \\
How to save energy & 0.094 & 5.68 \\
Temporal comparison & 0.093 & 5.51 \\
\hline
\end{tabular}

According to the importance-performance table (Table 2), the two most prominent drivers of energy saving were commitment to energy saving through pledging and saving money. It is noteworthy that although commitment to energy saving through pledging was the most important determinant of energy saving, Thais' commitment to energy saving through pledging is not as high when compared to their perception of money saving through energy saving in spite of its being second in importance as a driver of energy saving. Other drivers, namely accepting energy saving as one's responsibility, knowing how to save energy, and comparing the current energy bill with that of the previous months, were more or less equal in terms of the influence on energy saving.

According to the descriptive statistics, the strategies of Thais for saving save energy can be ranked from the most to the least used as follows: the first is rewards; the second is social comparison by providing information about their electricity utilization compared to their neighbors; and the last is the competition. Specifically, the mean values of these strategies were 5.21, 4.23 and 3.84 respectively and these strategies were measured on the seven-point scale from 1 meaning very little to 7 meaning very much. These results are in line with some previous studies. That is to say, some field studies have indicated that economic rewards (e.g., money or prizes) have been successful in reducing household energy consumption (Winett et al., 1978; Midden et al., 1983; McClelland \& Cook, 1980; Petersen et al., 2007). Moreover, social comparisons can be an effective strategy in motivating people to save energy because it facilitates social learning about the individuals' optimal level of energy use (Cai et al., 2009; Munshi \& Myaux, 2006). Comparative feedback demonstrates relevant social norms in favor of energy conservation-that is, it becomes clear that others are actively engaged in energy consumption as well. Some academic work has shown that providing social norm information induces people to conserve energy (Schultz et al., 2007; Nolan et al., 2008; Allcott, 2011).

\section{Conclusion}

The factors affecting residential energy saving in Thailand were found to be money saving, taking energy saving as one's responsibility, knowing how to save energy, commitment to energy saving through pledging, and comparing one's current energy bill with the previous months. Among these motivators of energy saving, commitment to energy saving through pledging and saving money are likely to be the most effective strategies in promoting energy saving at home. However, other candidate strategies for saving energy are taking energy saving as one's responsibility, knowing how to save energy, and comparing the current energy bill with the that of the previous months.

\section{References}

Abrahamse, W., \& Steg, L. (2009). How do socio-demographic and psychological factors relate to households' direct and indirect energy use and savings? J. of Economic Psychology, 30(5), 711-720. doi:10.1016/j.joep.2009.05.006

Abrahamse, W., \& Steg, L. (2011). Factors related to household energy use and intention to reduce it: The role of psychological and socio-demographic variables. Human Ecology Review, 18(1), 30-40.

Albert, S. (1977). Temporal comparison theory. Psychological Review, 84(6), 485-503. doi:10.1037/0033-295x.84.6.485

Allcott, H. (2011). Social norms and energy conservation. Journal of Public Economics, 95(9-10), 1082-1095. doi:10.1016/j.jpubeco.2011.03.003

Aravena, C., Riquelme, A., \& Denny, E. (2016). Money, comfort or environment? Priorities and determinants of energy efficiency investments in Irish households. Journal of Consumer Policy, 39(2), $159-186$. doi:10.1007/s10603-016-9311-2

Asian Development Bank. (2015). Energy efficiency developments and potential energy savings in the Greater 
Mekong Subregion. Retrieved from http://EconPapers.repec.org/RePEc:asd:wpaper:rpt146840-2

Attari, S. Z., DeKay, M. L., Davidson, C. I., \& Bruine de Bruin, W. (2010). Public perceptions of energy consumption and savings. Proceedings of the National Academy of Sci, 107(37), 16054-16059. doi:10.1073/pnas.1001509107

Baird, J. C., \& Brier, J. M. (1981). Perceptual awareness of energy requirements of familiar objects. Journal of Applied Psychology, 66(1), 90-96. doi:10.1037/0021-9010.66.1.90

Becker, L. J. (1978). Joint effect of feedback and goal setting on performance: A field study of residential energy conservation. Journal of Applied Psychology, 63(4), 428-433. doi:10.1037/0021-9010.63.4.428

Bolderdijk, J. W., Steg, L., Geller, E. S., Lehman, P. K., \& Postmes, T. (2013). Comparing the effectiveness of monetary versus moral motives in environmental campaigning. Nature Climate Change, 3(4), 413-416. doi:10.1038/nclimate1767

Bord, R. J., O'Connor, R. E., \& Fisher, A. (2000). In what sense does the public need to understand global climate change? Public Understanding of Science, 9(3), 205-218. doi:10.1088/0963-6625/9/3/301

Cai, H., Chen, Y., \& Fang, H. (2009). Observational learning: Evidence from a randomized natural field experiment. American Economic Review, 99(3), 864-882. doi:10.1257/aer.99.3.864

Clark, P. W., Martin, C. A., \& Bush, A. J. (2001). The effect of role model influence on adolescents' materialism and marketplace knowledge. J. of Marketing Theory \& Practice, 9(4), 27-36. doi:10.1080/10696679.2001.11501901

Fitzpatrick, G., \& Smith, G. (2009). Technology-enabled feedback on domestic energy consumption: Articulating a set of design concerns. IEEE Pervasive Computing, 8(1), 37-44. doi:10.1109/mprv.2009.17

Frick, J., Kaiser, F. G., \& Wilson, M. (2004). Environmental knowledge and conservation behavior: Exploring prevalence and structure in a representative sample. Personality and Individual Differences, 37(8), 1597-1613. doi:10.1016/j.paid.2004.02.015

Grob, A. (1995). A structural model of environmental attitudes and behaviour. Journal of Environmental Psychology, 15(3), 209-220. doi:10.1016/0272-4944(95)90004-7

Han, H., Hsu, L.-T. (Jane), \& Sheu, C. (2010). Application of the theory of planned behavior to green hotel choice: Testing the effect of environmental friendly activities. Tourism Management, 31(3), 325-334. doi:10.1016/j.tourman.2009.03.013

Harland, P., Staats, H., \& Wilke, H. A. M. (2007). Situational and personality factors as direct or personal norm mediated predictors of pro-environmental behavior: Questions derived from norm-activation theory. Basic and Applied Social Psychology, 29(4), 323-334. doi:10.1080/01973530701665058

Hines, J. M., Hungerford, H. R., \& Tomera, A. N. (1987). Analysis and synthesis of research on responsible environmental behavior: A Meta-analysis. The Journal of Environmental Education, 18(2), 1-8. doi:10.1080/00958964.1987.9943482

Hummel, C. F., Levitt, L., \& Loomis, R. J. (1978). Perceptions of the energy crisis. Environment and Behavior, 10(1), 37-88. doi:10.1177/0013916578101003

Kollmuss, A., \& Agyeman, J. (2002). Mind the gap: Why do people act environmentally and what are the barriers to pro-environmental behavior? Environmental Education Res, 8(3), 239-260. doi:10.1080/13504620220145401

Leelakulthanit, O. (2017). Barriers and benefits of changing people's behavior regarding energy saving of air conditioners at home. Asian Social Science, 13(10), 130-136. doi:10.5539/ass.v13n10p130

Lokhorst, A. M., Werner, C., Staats, H., van Dijk, E., \& Gale, J. L. (2013). Commitment and behavior change: A meta-analysis and critical review of commitment-making strategies in environmental research. Environment and Behavior, 45(1), 3-34. doi:10.1177/0013916511411477

McClelland, L., \& Cook, S. W. (1980). Promoting energy conservation in master-metered apartments through group financial incentives1. J. of Applied Social Psychology, 10(1), 20-31. doi:10.1111/j.1559-1816.1980.tb00690.x

Meinhold, J. L., \& Malkus, A. J. (2005). Adolescent environmental behaviors. Environment and Behavior, 37(4), 511-532. doi:10.1177/0013916504269665

Midden, C. J. H., Meter, J. F., Weenig, M. H., \& Zieverink, H. J. A. (1983). Using feedback, reinforcement and information to reduce energy consumption in households: A field-experiment. Journal of Economic Psychology, 3(1), 65-86. doi:10.1016/0167-4870(83)90058-2

Munshi, K., \& Myaux, J. (2006). Social norms and the fertility transition. Journal of Development Economics, 80(1), 1-38. doi:10.1016/j.jdeveco.2005.01.002

Nolan, J. M., Schultz, P. W., Cialdini, R. B., Goldstein, N. J., \& Griskevicius, V. (2008). Normative social influence is underdetected. Personality and Social Psychology Bulletin, 34(7), 913-923. doi:10.1177/0146167208316691

Pallak, M. S., Cook, D. A., \& Sullivan, J. J. (1980). Commitment and energy conservation. In L. Bickman (Ed.), Applied social psychology annual (Vol. 1, pp. 235-253). Beverly Hills, CA: Sage.

Pardini, A. U., \& Katzev, R. D. (1983). The effect of strength of commitment on newspaper recycling. Journal of 
Environmental Systems, 13(3), 245-254. doi:10.2190/6pn9-mxfp-3bff-chhb

Petersen, J. E., Shunturov, V., Janda, K., Platt, G., \& Weinberger, K. (2007). Dormitory residents reduce electricity consumption when exposed to real-time visual feedback and incentives. International Journal of Sustainability in Higher Education, 8(1), 16-33. doi:10.1108/14676370710717562

Roberts, S., Humphries, H., \& Hyldon, V. (2004). Consumer preferences for improving energy consumption feedback. Retrieved from https://www.ofgem.gov.uk/sites/default/files/docs/2004/08/8144-consumer_fdbak_pref.pdf

Schahn, J., \& Holzer, E. (1990). Studies of individual environmental concern. Environment and Behavior, 22(6), 767-786. doi:10.1177/0013916590226003

Schuitema, G., \& Steg, L. (2005). Percepties van energieverbruik van huishoudelijke apparaten (Perception of energy use of domestic appliances). In A. E. Bronner, P. Dekker, E. de Leeuw, K. de Ruyter, A. Smidts, and J. E. Wieringa (Eds.), Ontwikkelingen in het marktonderzoek, Jaarboek MarktOnderzoekAssociatie (Developments in marketing research, Yearbook Market Research Association) (pp. 165-180). Haarlem: De Vrieseborch.

Schultz, P. W., Nolan, J. M., Cialdini, R. B., Goldstein, N. J., \& Griskevicius, V. (2007). The constructive, destructive, and reconstructive power of social norms. Psych. Sci., 18(5), 429-434. doi:10.1111/j.1467-9280.2007.01917.x

Steg, L., Dreijerink, L., \& Abrahamse, W. (2005). Factors influencing the acceptability of energy policies: A test of VBN theory. Journal of Environmental Psychology, 25(4), 415-425. doi:10.1016/j.jenvp.2005.08.003

Steg, L., \& Groot, J. (2010). Explaining prosocial intentions: Testing causal relationships in the norm activation model. British Journal of Social Psychology, 49(4), 725-743. doi:10.1348/014466609x477745

Steg, L., Perlaviciute, G., \& van der Werff, E. (2015). Understanding the human dimensions of a sustainable energy transition. Frontiers in Psychology, 6. doi:10.3389/fpsyg.2015.00805

Steg, L., Perlaviciute, G., van der Werff, E., \& Lurvink, J. (2014). The significance of hedonic values for environmentally relevant attitudes, preferences, and actions. Environment and Behavior, 46(2), 163-192. doi:10.1177/0013916512454730

Taufik, D., Bolderdijk, J. W., \& Steg, L. (2014). Acting green elicits a literal warm glow. Nature Climate Change, 5(1), 37-40. doi:10.1038/nclimate2449

U. S. Department of Energy. (2013). Report: Motivating home energy improvements: Focus groups for the U. S. Department of Energy. Retrieved from https://energy.gov/sites/prod/files/2013/11/f5/doe_fg_report.pdf

Van der Werff, E., \& Steg, L. (2015). One model to predict them all: Predicting energy behaviours with the norm activation model. Energy Research \& Social Science, 6, 8-14. doi:10.1016/j.erss.2014.11.002

Van Raaij, W. F., \& Verhallen, T. M. M. (1983). A behavioral model of residential energy use. Journal of Economic Psychology, 3(1), 39-63. doi:10.1016/0167-4870(83)90057-0

Van Raaij, W. F., \& Verhallen, T. M. M. (1983). Patterns of residential energy behavior. Journal of Economic Psychology, 4(1), 85-106. doi:10.1016/0167-4870(83)90047-8

Venhoeven, L. A., Bolderdijk, J. W., \& Steg, L. (2013). Explaining the paradox: How pro-environmental behaviour can both thwart and foster well-being. Sustainability, 5(4), 1372-1386. doi:10.3390/su5041372

Vicente-Molina, M. A., Fernández-Sáinz, A., \& Izagirre-Olaizola, J. (2013). Environmental knowledge and other variables affecting pro-environmental behaviour: Comparison of university students from emerging and advanced countries. Journal of Cleaner Production, 61, 130-138. doi:10.1016/j.jclepro.2013.05.015

Werner, C. M., Turner, J., Shipman, K., Shawn Twitchell, F., Dickson, B. R., Bruschke, G. V., \& von Bismarck, W. B. (1995). Commitment, behavior, and attitude change: An analysis of voluntary recycling. Journal of Environmental Psychology, 15(3), 197-208. doi:10.1016/0272-4944(95)90003-9

Wetherill, G. B., Duncombe, P., Kenward, M., Paul, S. R., \& Vowden, B. J. (1986). Regression analysis with applications. (1986). London: Chapman and Hall.

Whitmarsh, L., Seyfang, G., \& O’Neill, S. (2011). Public engagement with carbon and climate change: To what extent is the public "carbon capable"? Global Environ. Change, 21(1), 56-65. doi:10.1016/j.gloenvcha.2010.07.011

Winett, R. A., Kagel, J. H., Battalio, R. C., \& Winkler, R. C. (1978). Effects of monetary rebates, feedback, and information on residential electricity conservation. Journal of Applied Psychology, 63(1), 73-80. doi:10.1037/0021-9010.63.1.73

Zhang, Y., Wang, Z., \& Zhou, G. (2013). Antecedents of employee electricity saving behavior in organizations: An empirical study based on norm activation model. Energy Policy, 62, 1120-1127. doi:10.1016/j.enpol.2013.07.036

\section{Copyrights}

Copyright for this article is retained by the author(s), with first publication rights granted to the journal.

This is an open-access article distributed under the terms and conditions of the Creative Commons Attribution license (http://creativecommons.org/licenses/by/4.0/). 